STRUČNI

ČLANAK

\title{
Film tourism as a tool of tourism development: The Representation of Scotland in the Outlander TV series
}

\author{
Ekranski turizam kao sredstvo razvoja \\ turizma: Predstavljanje Škotske u TV seriji \\ "Tuđinka"
}

\author{
Jasna Potočnik Topler, Faculty of Tourism, Brežice, Slovenia \\ Tjaša Špenko, Faculty of Tourism, Brežice, Slovenia
}

ABSTRACT

Keywords: Screen tourism,

Scotland,

Outlander series,

Destination

depiction,

Perception

SAŽETAK

Keywords: filmski turizam,

Škotska,

serija „Tuđinka", opis destinacije,

percepcija
This article examines the phenomenon of the latest niche trend that has emerged in the Tourism industry and represents a great part of one destination's economy. It runs under several names, such as Film-induced Tourism, Screen Tourism, Set-Jetting, or, most simply, Film Tourism. The currently trendy story of Outlander, written by Diana Gabaldon and first published in 1990, was examined and analysed in the article. Through what is presently eight thick volumes, we follow the story of two main protagonists, the rebellious but honest Scottish warrior James Fraser, and a 20th century independent but devoted Englishwoman, Claire Randall. The title of the very first book is Outlander, meaning a person who does not come from that particular area and is, in fact, an outsider. Back in the 18th century, to where the mentioned book dates, it also meant an Englishman. The following paper focuses on the important impact of the Outlander series, also named 'Outlander effect', on the perception of Scotland and its heritage around the globe, as well as on Scottish tourist visitation since the TV adaptation of the eponymous name aired in 2014.

Ovaj članak ispituje fenomen jednog aktuelnog nišnog trenda koji je zabeležen u turizmu i koji predstavlja veliki deo ekonomije jedne destinacije. On se pojavljuje pod raznim nazivima, kao što su "filmski indukovan turizam”, „ekranski turizam”, „set-džeting” ili, najprostije, filmski turizam. Detaljno se analizira trenutno popularna priča o "Tuđinki“, koju je napisala Dajana Gabaldon i koja je prvi put objavljena 1990. U osam do sada objavljenih obimnih tomova, pratimo priču dvoje glavnih protagonista - buntovnog, ali pravičnog škotskog ratnika, Džejmsa Frejzera i nezavisne, ali odane Engleskinje iz XX veka, Kler Rendal. Naslov prve knjige serijala je "Outlander", što označava osobu koja ne potiče iz tog kraja i koja je, u stvari, tuđin. U XVIII veku, u kome se odvija radnja knjige, ova reč je označavala i Engleza. Ovaj rad se bavi velikim uticajem serije „Tuđinka”, poznatim i pod nazivom „efekat Tuđinke”, na globalnu percepciju 
Škotske i njenog nasleđa, kao i na broj turističkih poseta Škotskoj od početka prikazivanja televizijske adaptacije istoimenog romana, 2014.

\begin{abstract}
"Oh, my dear, there's no place on Earth with more magic and superstition mixed into its daily life than the Scottish Highlands".
\end{abstract}

(Frank Randall, Outlander)

\section{Introduction}

Screen tourism is one of the recent tourism trends, and an area of research that is gaining its popularity, suggesting that films can lead to an increased influx of tourists to destinations featured in films (Riley \& Van Doren, 1992; Rudowsky, 2014). Many Hollywood blockbuster films have had a huge impact on Tourism, encouraging tourists from around the world to travel to specific destinations shown or mentioned in the films or on screen (Agarwal \& Shaw, 2018), e. g. Mamma Mia on Greece, Vicky, Cristina, Barcelona on Barcelona and Spain, Before Sunrise on Vienna, Game of Thrones on Dubrovnik, Lord of the Rings on New Zealand, which is one of the most successful examples of branding a destination through film, etc. Several studies have already illustrated and confirmed that destination images (also those based on film or screen depictions) influence tourist behaviour (among the earliest researchers were Hunt, 1975; Pearce, 1982; Echtner \& Ritchie, 1991 etc.). Destination image has an essential and significant role in the process of branding and marketing a destination (Potočnik Topler \& Zekanović-Korona, 2018), and, according to Pike and Ryan (2004), to position a destination successfully in the marketplace. When it comes to positioning a destination, film has, in fact, also generated interest as a tool of Destination Marketing because it can reach mass audiences and is perceived to be trustworthy (Connell, 2005; Tasci, 2009). In a relatively short period of time, a larger number of people can watch a film or a television (TV) series, which might have a major impact on the perception of a particular destination, as well as the destination's image. Success of a film or TV series can, thus, have a very positive effect on the destination's visitation. Given the steady growth and great impact on the economy, and despite being a niche activity, this relatively new study requires further analysis and more detailed research. As such, it is well worthy of greater attention.

Scotland has always been recognisable as the land of many legends, myths, folk tales and curious superstitions, as well as overwhelming landscapes, islands and numerous castles that provide inspiration for many intriguing plots and stories. As such, it appears as part of many historical novels and romances, films and TV series. Among others, a few of the very popular subjects are the everlasting conflicts between sophisticated and noble Englishmen and rebellious and fearsome Scotsmen, as well as infamous bloodshed amid Scottish clans, not infrequently consisting of publicly unacceptable love affairs that spice up the story and attract a greater number of readers or viewers.

This paper examines one of the latest tourism booms in Scotland, related to the field of Screen Tourism. The TV adaptation of Diana Gabaldon's best-selling novels that originate in the Scottish Highlands is being filmed in Scotland itself, and causes great excitement, as well as increased visitation to certain story-related locations. The main plot is explained superficially and Scotland's depiction is presented further on in the paper. The case of Scotland is interesting, because it can also be transferred to other destinations with rich natural and cultural heritage.

\section{Materials and methods}

The methods of content analysis and data analysis and, partly, participant observation in the field, have been employed in examining Screen Tourism in Scotland, or, to be more precise, the so-called 'Outlander effect' that was triggered by Gabaldon's books-based TV series, presented thoroughly in this article.

Several web sources were reviewed and, later, analysed in order to understand the described phenomenon fully. The main database for the analysis of the stories in question and its TV adaptation are the official website of Outlander's author, Diana Gabaldon, and Scotland's main online tourism information platform, VisitScotland. For better evaluation of the subject, as well as easier rendering, the first three of the books in question were 
read - Outlander, Dragonfly in Amber, and Voyager - and all four season of eponymous TV series were watched. Furthermore, the depiction of Scotland through setjetting, as well as Outlander based statistical data of recent visitations, are supported by numerous articles, publications and online journals.

Additionally, a visit was paid to Scotland last autumn to witness the Outlander effect and visit its film locations.

\section{The phenomenon of Screen Tourism}

Film Tourism, which is defined as "tourist visits to a destination or attraction as a result of the destination's being featured on television, video, or the cinema screen" by Hudson and Ritchie (2006), has become a widely recognised phenomenon due to its enormous growth in recent years, and, due to the increased number of authors employing the terms Film Tourism, Film-induced Tourism, Movie or Screen Tourism in their scientific research, which additionally consolidated the area in the academic community (Cardoso, Esrevao, Fernandes, \& Alves, 2017).

Certain motion pictures increase the awareness of the site they depicted and have tourist inducing effects (Busby \& Klug, 2001). The depiction of a certain destination on screen is a key motivator for a tourist to visit it. People either want to revive the storyline, are drawn by the location's scenery, exciting sequences or human relationships (Riley, Baker, \& van Doren, 1998). Furthermore, this relatively new branch is fuelled by the growth of the entertainment industry and increase in international travel (Hudson \& Brent Ritchie, 2006). A larger data base is required to understand and better predict its far-reaching repercussions fully. Not all films and TV series show equal success, although, they do have a significant impact on a destination (Riley, Baker, \& Van Doren, 1998). Film-induced Tourism is a great tool for destination image development and its marketing, even though attracting more visitors and tourists to certain regions is not a primary reason for fim making (Hudson \& Brent Ritchie, 2006). Although insufficiently explored and in some ways underestimated, its benefits are becoming apparent.

\section{Taking advantages of film industries}

Not only that individuals visit film locations because of scenic landscape, captivating cities, picture perfect camera angles or other physical features of one's location, but, as mentioned before, film subject, favourite performer, special events, deeper personal meaning, or even special effects can be persuasive enough. Alternatively, anything extraordinary would also do the trick in some cases (Riley, Baker, \&Van Doren, 1998).

There are a few success factors to pay attention to when dealing with possible Film-induced Tourism. Hudson and Brent Ritchie (2006) introduced the first theoretical model, presenting key influences to pay attention to. They suggest Film Tourism depends on five factors, such as destination marketing activities, destination attributes, film-specific factors, film commission and government efforts and location feasibility.

Destination Marketing activities are divided between 'before release' and 'after release' activities. Hudson and Brent Ritchie (2006) suggest 'before release' activities should, among others, include active promotion of a destination to film studios, grants and tax credits encourage studios to use the location in the first place, carefully prepared plans to maximise the impacts of post-production exposure, end credits' negotiation for the destination, as well as production of "making of the film" feature (its demand is growing), film stars engagement to promote the film location, images used in promotion via media and Tour Operators, invitation to travel media to the film location, media coverage of the film mentions the film location, and so on.

Differing from 'after release' that should consist of invitations to travel media to a special release of the film, post signage and interpretation at the location, film memorabilia sale, maintenance of film sets to maintain authenticity, potential tourists dedicated Web site, constant activity on social media, cooperation with public organisations and tourist authorities to promote film locations, as well as accommodations used on the screen, joint promotional activities, guided tours and film walks, thematic exhibitions or displays or other ways to attract media attention continuously to the location (Hudson \& Brent Ritchie, 2006).

When talking about destination attributes, they relate to its scenery, sets, backdrop, as well as icons, awareness and brand. Nonetheless, Film Tourism also depends on the success of the film itself, accessible location to film sets, amount of its exposure on screen, untainted environments, as well as emotional attachment of the viewers. Active promotion is required from the government itself, along with establishment of dedicated Web sites or possible tax breaks. A location's available 
Potočnik Topler, J., Špenko, T. - Film tourism as a tool of tourism development

resources, cost, labour and expertise should also be taken into account (Hudson \& Brent Ritchie, 2006).

The demand for visits to film locations and "making of the film" videos are growing rapidly. In order to use it to your advantage and make business out of it successfully, you should be able to recognise its potential, adapt and use it, and then wait for it to flourish in its full dimensions.

\section{Outlander by Outlander book series}

"Absorbing and heartwarming... lavishly evokes the land and lore of Scotland," states a review by Publishers Weekly about Outlander, written by Diana Gabaldon (Books in Order, 2010). Gabaldon is an American University Professor and award-winning New York Times bestselling author of the Outlander book series. She has written comic books for Walt Disney and many other papers in her past. However, she has dedicated her last 20 years to stories about a Scottish Highlander and his wife. She is neither Scottish nor English, but has ancestors from England. She was born and raised in the state of Arizona, USA (Gabaldon, 2016a \& 2019b).

Gabaldon has three degrees in science - Zoology, Marine Biology and Ph.D. in Quantitative Behavioral Ecology. Being a novelist was something on her to-do list back in the 1980s. She wrote the first book, Outlander, for practice. Her main goal was to see what it took to write a novel, and, later on, to decide whether she wanted to do just that. The content for the book was drawn exclusively from the library, since Gabaldon had not visited Scotland before that. Today, she is writing the 9th book from the mentioned book series, her bibliography contains many more, and she pays visits to the Highlands as frequently as possible (Gabaldon, 2016a \& 2016b).

Outlander, the very first book from the Outlander book series, was first published in 1990 in the USA. It was followed by Dragonfly in Amber (1992), Voyager (1993), Drums in Autumn (1996), The Fiery Cross (2001), A Breath of Snow and Ashes (2005), An Echo in the Bone (2009), Written in My Own Heart's Blood (2014), meanwhile, Go Tell the Bees That I Am Gone is still being written. Besides "the big, enormous books," as Gabaldon calls them, the Outlander series also includes "the shorter, less indescribable novels," which are mostly historical novels, and "the bulges," short stories that fit inside the books somewhere and talk mostly about secondary Outlander characters (Gabaldon, 2019a). However, all the books are designed to be read separately and independently of each other if wanted. The book series has sold more than 28 million copies in print worldwide. It was reproduced in 26 countries and translated to 23 languages (Gabaldon, 2016a \& 2019b).

What is the plot of the Outlander book, also known as Cross Stitch in the United Kingdom? The story begins in the year 1946. WW II is finally over, and a young Englishwoman, an ex-combat Nurse named Claire Beauchamp Randall, is reunited with her husband, Frank, on their second honeymoon in the Scottish Highlands. On one of her walks, Claire comes across an ancient circle of standing stones. She touches the one in the middle and instantly disappears into thin air. Suddenly, she is found in a strange land. She becomes a Sassenach, an outlander in the midst of wars amongst Highland clans, in the year 1743. She finds herself caught in plots and schemes that put her life - and her heart - in jeopardy. Claire succeeds a deceased healer of the Mackenzie clan in order to survive. She tries to adapt to unknown life in a land where she does not speak the language, know the customs, or understand what she sees. To save her life from a cruel fate, she is forced to marry a young and handsome Scottish warrior - and a wanted man - James Fraser. She becomes a woman torn between fidelity and desire, and two completely different husbands in two incompatible lives. As described by its author, it is a story of hope and despair, love, honour, betrayal, vengeance, sex, relationships, family, warfare, rebellion, and much more (Gabaldon, 2016b \& 2019c).

\section{From the book to tv adaptation}

The phenomenon of Outlander has spread all over the globe. It is no surprise that the first episode of the TV series bearing the same name premiered in the year 2014 (Ronald D. Moore, 2014-present) (IMDB, 20142019). It was produced by the Starz Network and Tall Ship Productions, and distributed by Sony International (Gabaldon, 2016a). Season 2 was aired in 2016, followed by the 3rd in 2017 and 4th in 2018. They are based on the first four books from Gabaldon's Outlander series. Seasons 5 and 6 are confirmed to air in the coming years. The main protagonists are Caitriona Balfe in the role of Claire Randall Fraser and Sam Heughan as James Fraser. The show won 27 awards, and was nominated for 55 more (IMDB, 2014-2019).

Furthermore, while we get to know Claire and Jamie in the first book, we follow their footsteps in the following 
sequels as well. We witness their fight for justice, desire to change the brutal path of history, all their ups and downs, the horrors of the 18th century, and life in general. Furthermore, there is a good deal of acts of violence. We witness torture, imprisonment, attempted sexual assaults and actual rape, murder, piracy, wars and battles, lethal diseases where no cure was yet invented, and even natural disasters. At certain stages of their lives, they move from the picturesque Scottish Highlands to Edinburgh, Paris in France, the West Indies, and even all the way to the colonies of North Carolina in America, in the midst of the forthcoming American Revolution, where their story continues (Gabaldon, 2019c).

\section{Depicition of Scotland through several aspects}

The scenery of Scotland is as picturesque as it can be. From snow-capped mountains in the far Highlands, lush green glens and wild lochs at the crossing, to beautiful historical sites and abbeys on the Scottish border, and windy islands at the Western part of the region - it is more than breathtaking - exactly what tourism discourse aims to show and sell using the magic framework and other tourism discourse techniques (Potočnik Topler, 2018). The unspoilt nature with its captivating touch is a fine destination for magic to come true. It offers a great deal of folk tales, from fairies to the Loch Ness monster, wandering across these hills and valleys.

The story of Outlander is built upon historically accurate details (Deluca, 2014). An episode from Dr. Who (Sydney Newman, 1963-1989; 2005-present) inspired Gabaldon to submerge herself into extensive study of Scottish history and write a plot that will, in a way, retell their past. First, she takes us through the final great Jacobite uprising that takes place in the Culloden Battlefield in 1745. We witness the rebellion against King George II, which is led by Bonnie Prince Charlie. The end of this brutal battle also means the end of the Clans of Scotland. The Clan system is crushed and their culture suppressed for hundreds of years. Furthermore, in the years to come, the American Revolution emerges (Watt, 2018), another history fact that Gabaldon decided to lean upon. In one of her interviews she admits the only time she wrote something inaccurate purposefully was when referring to the witch trial in the first book. The last record of such doings was from 1722, yet her story was set about two decades later (Deluca, 2014). Gabaldon based her books on underlying historical events, shaped to fit her ideas and filmed at real-life locations throughout Scotland.
While reading Outlander books or watching the TV series, we come across a colourful dialect. This mixture of Gaelic, Germanic, Dutch and French words, known as Scottish Gaelic, often referred to as Scots Gaelic, or simply Scots, is an older version of the Gaelic language (Watt, 2018). It is a founding language of Scotland, thought to originate from Ireland (VisitScotland, 2019b). Scots was spoken mainly in rural areas, and was banned after the Battle of Culloden because of the connection with Scottish Jacobites (Watt, 2018). Consequently, its speakers were persecuted, the dialect was forced out of education and, later, media and business life (VisitScotland, 2019b).

Scots, one of the largest minority languages in Europe, was reborn in recent years, and Outlander happens to be a great part of its rehabilitation. The use of Gaelic as part of the story has had a positive effect on Scottish culture, identity and heritage. The primary reason Gabaldon used it was to lend more authenticity to the drama (Watt, 2018). One of the most iconic examples of Gaelic appearing in both, book and TV series is Jamie's affectionate name for his wife, "Sassenach," meaning an English person or an outlander.

The perception of Gaelic today has changed, and its status has improved. Scottish Gaelic appears in media, and is supported by the Council of Europe Charter on Minority Languages, as well as being taught in schools and universities as an elective course. However, the language from the mid-18th century differs slightly from the one spoken today (Watt, 2018).

Scotland used to be the land of Clans and, after Gabaldon's books, the interest in Scottish history keeps growing. But what happened at that crucial point in history, leaving such tragic consequences on communities and the infrastructure of the Highlands? That takes us back to the infamous Battle of Culloden in 1746. After the tragic defeat, Clans were banned, and, in a way, they ceased to exist in its original form. Nevertheless, over 500 Clan families are still registered today, hosting gatherings to celebrate Scottish heritage all over the globe (VisitScotland, 2019a).

However, let's go back a few years to the point, where Outlander starts -1743 . What was Scotland like back then?

Scotland in the 1740s was a country divided between Highlands and Lowlands. Before the Jacobite rebellion, the land was split among many Clans in the Highlands. Its valleys were full of people, as they lived mostly in the rural areas. Furthermore, a clansman's main goal was to feed his family. In the hinterland, they most 
likely tended the fields and some livestock, while on the coast they mastered fishing, breeding sheep or cattle, sometimes even growing small amounts of crops. The commerce was often carried out by bartering. Highland farmers took instructions from their chiefs, or so-called landlords, which is apparent even in Outlander. Their main language was Gaelic, but knowledge of English was quite common as well. Clansmen entertained themselves with storytelling, poetry and music. However, it was all passed orally from generation to generation, since writing was not widely distributed in the lower classes. The rebellion in 1746 triggered the need for education, but it was, unfortunately, drawn away from their traditional way of life. Scottish Highlanders were mostly Episcopalian, and not Catholic as many believed (McCall, 2016).

What is the first thing that comes to your mind when asked about Scotland? Bagpipes and whisky? Maybe. What about the legendary historic piece of clothing, known as the kilt?

Scottish tartan with its horizontal and vertical stripes is the main ingredient used to make a kilt. Scotsmen wear it around the waist, along with a small bag (sporran) and a small dagger (sgian dubh). The two pieces of kilt are held together at the front by a kilt pin (VisitScotland, 2019c). Another version is plaid, originally a larger piece of untailored 5-metre long cloth, much like a blanket. While one part is buckled around the waist by a belt, the remainder goes over one shoulder and is pinned to the chest of the jacket in the front. Tartan, as well as the kilt, originated in the Highlands, and are shown on screen (VisitScotland, 2019c).

The clothing in the mid-18th century was usually washed out and sun bleached, as people in that area belonged to a lower class. The colours were a matter of wealth. The wealthier, the brighter (Barks, 2015). Men wore either trews (trousers) or a kilt, whichever they preferred. The kilt might have been more unusual, but quite handy on occasion. Moreover, Scottish hats are irrefutable and always present. That is evident in the TV series as well. 1746s Dress Act banned the wearing of tartan and Highland dress. Tartan was, incorrectly, believed to be a symbol of the Jacobites and, as such, of resistance. However, their true mark was a white cockade in their hats. Today, tartan is a very powerful marketing tool all over the country (Barks, 2015).

The team from Outlander did their research on the topic, and tried to make the TV series as authentic as possible. They did, however, tailor the clothing every now or then to meet the expectations and demands of the viewers (Barks, 2015).

\section{The impact of Outlander on Scottish tourism and economy}

The depiction of Scotland in all its glory in Gabaldon's stories lures masses of fans to travel to Edinburgh and explore the Highlands. The book-based TV series popularises Scottish history, introduces an authentic picture of the 18th century life, entertains viewers with folk tales, makes them fall in love with love as much as with the dashing main characters (Garavelli, 2014). Sam Heughan, playing the role of James Fraser, told ELLE in one of his interviews that about $50 \%$ of the show's audience is male due to common scenes of violence (as well as sex, of course) (Wood, 2017). What is interesting is that, on the contrary, the surveys show that as many as $77 \%$ of Outlander visitors to Scotland are female (VisitScotland, 2019d).

VisitScotland monitors tourist figures in the region regularly. A large increase in tourism visitation was recorded in 2017 due to a number of factors that worked in union. Office for National Statistics (ONS) data show that the figures in this year are the highest reported since the ONS travel trends survey started in 1961/62 (Webster, 2018). One of the key elements is most certainly the perceived safety, and Scotland is considered a relatively safe country. Additionally, the current political situation and the question of Brexit had a huge impact on the pound sterling. Weaker currency, after all, means more favourable holidays on the Island. In recent years, some additional air links were established, and Scotland became more accessible than ever. However, the power of film industries, as TV series and film locations based in Scotland that attract millions should not be neglected (Gallagher, 2018).

Filming at a destination usually leaves a footprint in the destination's economy. The Outlander crew, composed of 200 members, obtained a permit to build their own studio in the region. They employed 2,000 actors from all over the UK and, in only 38 weeks of filming the series in the years 2013/14, they contributed no less than $£ 20$ million to the country's economy (Garavelli, 2014).

In 2017, the film and television industry brought record profits to Scotland, and was worth $£ 95$ million, up by as much as $300 \%$ over the last decade. This calculation includes the Outlander TV series, along with the films 
Avengers: Infinity War (Anthony Russo, 2018) and Outlaw King (David Mackenzie, 2018) (Riordan, 2018). Many movies were filmed in Scotland in recent years, but not many raised any particular attention (Braveheart (Mel Gibson, 1995) being excluded). Furthermore, until recently, Scotland did not have its own film studio. Thanks to Outlander, they now have their own facility, which will be transformed into an international studio (Fraser, 2018).

With about 1.5 million viewers watching new episodes within the week, it is expected its popularity will have an impact on something (Stuever, 2018). The show was distributed to over 87 territories, particularly European and long haul markets. Countries such as the USA, Australia and China might stand out, but France, Germany, Spain, Canada, the Netherlands, Italy, Belgium and many others are strong too. Analyses also show an increase in TV programme influence on visitation to film locations (VisitScotland, 2019d). Credited by delivering a major boost in the tourism visitation and economy, as well as Scotland outperforming the rest of the UK in attracting visitors to its tourist sites, it was then tagged as the 'Outlander effect' (Fraser, 2018).

Table 1. List of a few Scottish attractions that were either presented in the series or used as filming locations

\begin{tabular}{lll}
\hline & Attraction & Outlander set \\
\hline 1 & Highland Folk Museum & Scottish villages \\
2 & Doune Castle & Castle Leoch \\
3 & Linlithgow Palace & Wentworth Prison \\
4 & Blackness castle & Fort William \\
5 & Hopetoun House & Home of the Duke of Sandringham \\
6 & Falkland & 20th century Inverness \\
7 & Drummond Castle Gardens & Park and orchard of the Palace of Versailles \\
8 & Glasgow Cathedral & L'Hospital Des Anges in Paris \\
9 & Midhope Castle & Lallybroch \\
10 & Culloden Visitor Centre & Battle of Culloden \\
11 & University of Glasgow & Harvard University \\
12 & Castle Fraser & inspired by only \\
13 & Glenfinnan Monument & inspired by only \\
\hline
\end{tabular}

(Source : The Authors)

Nevertheless, the interest in such offers helped raise visitation in $2017.14 .6 \%$ of overseas and $10 \%$ boost of domestic travellers were recorded over the period from July to September that year (Donnelly, 2018). Even the annual Visitor Trends Report revealed astounding results. The Association of Scottish Visitor Attractions (ASVA), for example, reported that more than 30 million visits were made to 232 of its member sites in Scotland, being just under a 10\% rise from 2016 (Gallagher, 2018). The summer season 2017 also recorded dramatic increases in visitation to the sites used as film locations in the Outlander TV series, in comparison to the previous year. In the period from June to September, Blackness Castle noted a $72 \%$, and Doune Castle a $50 \%$ boost, from the same period in 2016. Aberdour Castle documented 58\% more visits, while Linlithgow Palace had a $43 \%$ increase and Glasgow Cathedral 39\% (Historic Environment Scotland, 2017). The visit of the Culloden Moor escalated by $28 \%$ from 2016 (Rice, 2018). 2017 was, therefore, a record breaking year, but even 2018 has astonishing results. Doune Castle still records a $14 \%$ increase in footfall, Blackness Castle a 36\% boom (VisitScotland, 2019d).

It was confirmed that Screen Tourism is very beneficial to the Tourism sector in the country. However, the demand for Outlander related elements began long before the TV adaptation, in the year 2001. Records show that visitors to Culloden Moor were asking a lot of questions about the gravestone of Clan Fraser, as well as how to walk from the battlefield to the Clava Cairns - Gabaldon's inspiration for the famous stone circle, Craigh na Dun (Garavelli, 2014). 
Nowadays, the tourist offer to Outlander fandom is rich and diverse. After the TV series was launched, the theme tours around Scotland soared (Garavelli, 2014). Maps describing the main film locations, as well as mentioned or only 'inspired by' places, that somehow reflect on the screen, overflew the web. For this reason, more and more tourists and visitors go on self-guided tours, following the many instructions found on-line.

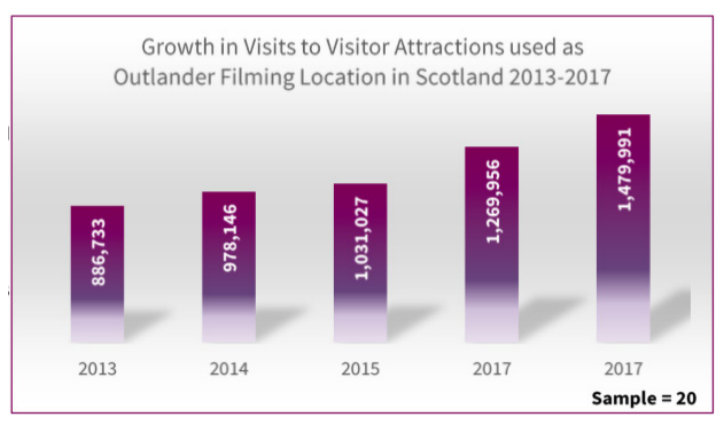

Figure 1. Growth in visits to visitor attractions used as Outlander filming location in Scotland, 2013-2017 (VisitScotland, 2019d).

Note. Copyright 2019d by VisitScotland.

Furthermore, conventions on the topic are being organised, along with different theme gatherings, extending exhibitions, and so on (VisitScotland, 2019d).

In response to all the activity, new partnerships are established inside the region, focusing on development of Sustainable Tourism products. There is, however, no fear of mass tourism so far, since Outlander takes places in many less known and more distant locations throughout the country (VisitScotland, 2019d).

\section{Conclusion}

Films, books and television series are beginning to gain importance in today's Tourism economy. Exploring the sites where an individual's favourite screen adventure took place, or reviving the story of tourists' beloved characters in the so-called original, authentic environment, is becoming more and more profitable.

Scotland took its most recent opportunity to become a world-renowned filming location by employing Gabaldon's Outlander book series and put it on the screen, which altered Scotland's recognition worldwide, and made it even more attractive for tourists. But what is it that makes Scotland so exceptional and appealing to tourists? Tourists' motives vary a great deal. Those who were encouraged and persuaded to visit Scotland due to the Outlander series, might enumerate several reasons from the uncertain future of the leading stars, put in the charming setting to perhaps the sinful, but unconditional and passionate love affair, portrayed in the series. Further research is needed to establish exact reasons. But whichever they are, they prove that Scotland has potential for pleasure as well as business. This could also be stated for many other destinations, not only in Western Europe, but also in its eastern parts and in the Balkan region, which itself boasts beautiful landscapes that offer many opportunities for film producers and, consequently, many opportunities for branding destinations by employing film as a branding tool. Nowadays, the use of traditional media in the formation of a destination image is insufficient, thus, tourism marketing could employ various elements of film and screen industry.

\section{STATEMENT}

In their statements, the authors confirmed the absence of any conflict of interest.

\section{REFERENCES}

Agarwal, S., \& Shaw, G. (2018). Heritage, Screen and Literary Tourism. Bristol: Channel View Publications.

Barks, B. (2015). The Real Deal on Tartan, Kilts, and Outlander Costumes. Retrieved from http://www.frockflicks.com/ the-real-deal-on-tartan-kilts-and-outlander-costumes/, 12.2.2019.

Books in order. (2010). Outlander Series - What the Critics Say. Retrieved from http://www.booksinorder.org/series/outlander/ critics, 23.2.2019

Busby, G., \& Klug, J. (2001). Movie-induced tourism: The challenge of measurement an other issues. Journal of Vacation Marketing, 7(4), 316-332.

Cardoso, L., Esrevao, C., Fernandes, C., \& Alves, H. (2017). Filminduced Tourism: A Systematic Literature Review. Tourism \& Management Studies, 13(3), 23-30.

Connell, J. (2005). Toddlers, tourism and Tobermory: Destination marketing issues and television-induced tourism. Tourism Management, 26(5), 763-776.

Deluca, A. N. (2014). Fictional Outlander Series Has Real Links to Scotland's Newly Unearthed Neolithic Ruins. Retrieved from https://news.nationalgeographic.com/ news/2014/08/140808-outlander-scotland-orkney-islandsstonehenge-neolithic/, 24.2.2019. 
Donnelly, B. (2018). Outlander brings 'phenomenal' tourism surge. Retrieved from https://www.heraldscotland.com/ news/15865614.outlander-brings-phenomenal-tourismsurge/, 23.2.2019.

Echtner, C. M., \& Ritchie J. R. B. (1991). The meaning and measurement of destination image. The journal of tourism studies, 2(2), 2-12.

Fraser, G. (2018). Outlander star: 'Scotland needs to capitalise on show's impact'. Retrieved from https://www.bbc.com/news/ uk-scotland-45993872, 1.3.2019.

Gabaldon, D. (2016a). About Diana. BIO. Retrieved from http://www. dianagabaldon.com/about-diana/bio/, 16.3.2019.

Gabaldon, D. (2016b). Outlander. Retrieved from http://www. dianagabaldon.com/books/outlander-series/outlander/, 16.3.2019.

Gabaldon, D. (2019a). Chronology of the Outlander series. Retrieved from http://www.dianagabaldon.com/books/chronology-ofthe-outlander-series/, 16.3.2019.

Gabaldon, D. (2019b). FAQ. About Diana. Retrieved from http:// www.dianagabaldon.com/resources/faq/faq-about-diana/, 16.3.2019.

Gabaldon, D. (2019c). The Outlander Series. Retrieved from http:// www.dianagabaldon.com/books/outlander-series/, 16.3.2019.

Gallagher, R. (2018). Romance of Outlander drives a new tourism boom. Retrieved from https://www.insider.co.uk/ special-reports/outlander-scottish-tourism-heughanvisitscotland-12543314, 16.3.2019.

Garavelli, D. (2014). Outlander sparks global interest in Scots heritage. Retrieved from https://www.scotsman.com/lifestyle/ culture/books/outlander-sparks-global-interest-in-scotsheritage-1-3497477, 17.3.2019.

Historic Environment Scotland. (2017). Historic sites celebrate 'Outlander effect'. Retrieved from https://www. historicenvironment.scot/about-us/news/historic-sitescelebrate-outlander-effect/, 16.3.2019.

Hudson, S., \& Brent Ritchie, J.R. (2006). Promoting Destinations via Film Tourism: An Empirical Identification of Supporting Marketing Initiatives. Journal of Travel Research, 44, (387).

Hunt, J. D. (1975). Image as a factor in tourism development. Journal of Travel Research, 13(3), 1-7.

IMDB. (2014-2019). Outlander. Retrieved from https://www.imdb. com/title/tt3006802/?ref_=ttep_ep_tt, 19.3.2019.

McCall, C. (2016). Outlander: What was life really like for Highland clansmen? Retrieved from https://www.scotsman.com/artsand-culture/tv-radio/outlander-what-was-life-really-like-forhighland-clansmen-1-4041907, 12. 3. 2019.

Pearce, P. L. (1982). Perceived changes in holiday destinations Annals of Tourism Research, 9, 145-164.

Pike, S., \& Ryan, C. (2004). Destination positioning analysis through a comparison of cognitive, affective, and conative perceptions. Journal of Travel Research, 42(4), 333-342.

Potočnik Topler, J., \& Zekanović-Korona, L. (2018). Digital media, perception and the selection of the 2016 Best European Destination: the case of Zadar. Annales: anali za istarske in mediteranske študije, Series historia et sociologia, 28(2), 343353. doi: 10.19233/ASHS.2018.23.
Potočnik Topler, J. (2018). Turning travelogue readers into tourists: representations of tourism destinations through linguistic features. Cuadernos de turismo, 42(1), 447-464.

Rice, L. (2018). Outlander fans are blamed for trampling on Clan Fraser grave in Scotland. Retrieved from https://ew.com/ tv/2018/04/16/outlander-clan-fraser-grave-cullodenbattlefield-scotland/, 24.3.2019.

Riordan, C. (2018). Film and TV spending in Scotland hits record L95m thanks to Avengers and Outlander. Retrieved from https://www. dailyrecord.co.uk/scotland-now/film-tv-spending-scotlandhits-13114692>, 16.3.2019.

Riley, R., Baker, D., \& Van Doren, C. S. (1998). Movie Induced Tourism. Annals of Tourism Research, 25(4), 919-935.

Riley, R., \& Van Doren, C. S. (1992). Movies of tourism promotion: A "pull" factor in a "push" location. Tourism Management, 13(3), 267-274.

Rudowsky, C. A. (2014). Movie Genre Effects on Destination Image, Place Familiarity, and Visitation Interest Among UndergraduateStudents: A Film Tourism Study (2014). Theses and Dissertations (All). 111.http://knowledge.library. iup.edu/etd/111. Retrieved from https://knowledge.library. iup.edu/cgi/viewcontent.cgi?referer=https://www.google. com/\&httpsredir=1\&article=1112\&context=etd, 8. 4. 2019.

Stuever, H. (2018). Sure, 'Outlander' is TV's sexiest show, but it's also a great lesson in how to listen. Retrieved from https:// www.washingtonpost.com/entertainment/tv/sure-outlanderis-tvs-sexiest-show-but-its-also-a-great-lesson-in-how-tolisten/2018/12/13/fc7c9758-f8c7-11e8-8c9a-860ce2a8148f_ story. html? noredirect $=$ on\&utm_term $=. c 35 \mathrm{db} 2865424$, 8.4.2019.

Tasci, A. D. A. (2009). Social distance: The missing link in the loop of movies, destination image, and tourist behavior? Journal of Travel Research, 47(4), 494- 507.

VisitScotland. (2019a). About clans. Retrieved from https://www. visitscotland.com/see-do/research-your-ancestry/clans/, 9.4.2019.

VisitScotland. (2019b). About Gaelic language \& history. Retrieved from https://www.visitscotland.com/about/uniquely-scottish/ gaelic/, 25.3.2019.

VisitScotland. (2019c). About tartan \& kilts. Retrieved from https:// www.visitscotland.com/about/uniquely-scottish/kilts-tartan/, 8.4.2019.

VisitScotland. (2019d). Insight Department: The Outlander Effect \& Tourism. Retrieved from https://www.visitscotland.org/ binaries/content/assets/dot-org/pdf/research-papers2/20190314-outlander-effect-2019.pdf., 27.3.2019.

Watt, I. (2018). Outlander is boosting a renaissance of Scots language - here's how. Retrieved from https://theconversation.com/ outlander-is-boosting-a-renaissance-of-the-scots-languageheres-how-101643, 8.4.2019.

Webster, C. (2018). Outlander effect pushes tourist numbers in Scotland to record high. Retrieved from https://www.scotsman. $\mathrm{com/business/companies/media-leisure/outlander-}$ effect-pushes-tourist-numbers-in-scotland-to-recordhigh-1-4771871, 26.3.2019.

Wood, J. M. (2017). 15 Surprising Facts About Outlander. Retrieved from http://mentalfloss.com/article/78374/15-surprisingfacts-about-outlander, 9.3.2019. 
Potočnik Topler, J., Špenko, T. - Film tourism as a tool of tourism development 2019. Fakultet za sport i turizam, Novi Sad, Tims.Acta 13, 79-88

Datum prijave: 10.09.2019.

Datum prihvatanja: 07.12.2019.

\section{Kontakt}

Jasna Potočnik Topler, University of Maribor,

Faculty of Tourism, Brežice

Cesta prvih borcev 36, Brežice, Slovenia

E-mail: jasna.potocnik1@um.si

Tjaša Špenko, student master studija,

University of Maribor, Faculty of Tourism, Brežice

Cesta prvih borcev 36, Brežice, Slovenia

E-mail: tjasa.spenko@student.um.si 